\title{
PROFIT, OUTPUT MARKET UNCERTAINTY, AND CORPORATE INVESTMENT: EVIDENCE FROM VIETNAM
}

\author{
Le Khuong Ninh*, Huynh Huu Tho, and Phan Anh Tu \\ College of Economics, Can Tho University, Campus II, 3/2 Street, \\ Ninh Kieu District, Can Tho City, Vietnam \\ *Corresponding author:1kninh@ctu.edu.vn
}

Published online: 29 June 2018

To cite this article: Le, K.N., Huynh, H.T., and Tu, P.A. (2018). Profit, output market uncertainty, and corporate investment: Evidence from Vietnam. Asian Academy of Management Journal, 23(1), 101-115. https://doi.org/10.21315/aamj2018.23.1.5

To link to this article: https://doi.org/10.21315/aamj2018.23.1.5

\begin{abstract}
This paper empirically investigates how the variation of profits affects the relationship between the degree of output market uncertainty and firm investment. Using a primary dataset of 667 firms randomly selected in Vietnam, the empirical results indicate that higher profits mitigate the negative impact of the degree of output market uncertainty on investment by those firms. Specifically, as profits go beyond a certain benchmark, output market uncertainty even triggers investment. Given the results, this paper proposes recommendations that enable firms to make better investment decisions, thereby avoiding over-investment that may lead to debt burden (even bankruptcy) as output markets somehow turn worse. More importantly, the implication of this paper is to help the government devise better policies for moderating competition, containing monopoly, and mitigating corruption.
\end{abstract}

Keywords: investment, irreversibility, profit, Vietnam, uncertainty

\section{INTRODUCTION}

Investment is key to firm establishment and growth. Making wise investment decisions will contribute to improving performance, therefore helping firms grow fast. Mistakes in making investment decisions that lead to over-investment will confront firms with hardships due to output market uncertainty, among others.

(C) Asian Academy of Management and Penerbit Universiti Sains Malaysia, 2018. This work is licensed under the terms of the Creative Commons Attribution (CC BY) (http://creativecommons. org/licenses/by/4.0/). 
Over-investment may occur as prior investments have brought about high profits, inducing firm to invest more regardless of output market uncertainty (Lin, $\mathrm{Hu}, \&$ Chen, 2005; Aggarwal \& Samwick, 2006; Deltas, 2006; Pinheiro, 2008; Fu, 2010; Liu \& Jiang, 2012). Thus, if output markets go down (for instance, as a result of economic crisis), firms may go bankrupt because of being unable to sell out products as a consequence of over-investment. This episode seems to be prevalent as to firms in Vietnam but few studies have dealt with it.

Vietnam is considered as an institutionally weak transition economy where the government still maintains a tight grip on the economy, especially regarding bank loans, business formation, investment magnitude, and finance (De Jong, Tu, \& van Ees, 2012). In such a context, building close relationships (network) with government officials is crucial since it helps firms tackle constraints imposed by bureaucratic procedures, obtain investment (business) licenses, and win contracts, thereby improving performance. Then, bribery can be regarded as an inevitable investment of firms (Peng \& Heath, 1996).

The aim of this paper is to examine the impact of profits on the relationship between output market uncertainty and investment by firms in Vietnam, using a primary data set of 667 firms randomly selected from the Mekong River Delta of this country. Findings of this paper shed further light on investment decisions of firms under output market uncertainty and give recommendations for firm managers to make good investments in order to improve performance and boost growth.

\section{LITERATURE REVIEW AND EMPIRICAL MODEL}

Capital is an indispensable factor to firm investment since investment depends primarily on the capital that firms have. Jorgenson (1963) assumes that capital markets are perfect, so using either internal or external funds make no difference for firms. In fact, capital market is basically imperfect due to asymmetric information between borrowers and lenders that results in default risk, among others. Hence, to minimise that risk, credit institutions eventually ration credit after raising interest rates up to a reasonable level, as pointed out by Stiglitz and Weiss (1981). If that is the case, firm investment should depend on internal funds, mainly profits (Guariglia, 2008; Engel \& Middendorf, 2009).

Meanwhile, when making investment decisions, firm managers do face output market uncertainty because of being unable to know the exact future sales. Market uncertainty stems from the skill of firm managers in terms of gathering relevant 
information. As time elapses, new information arrives and firm managers take it into account to adjust activities, including investment decisions, so as to make use the most of the socio-economic condition that constantly changes, for instance due to the sovereign cost of borrowing embedded in government bonds (Dergiades, Milas, \& Panagiotidis, 2015). Indeed, as government bond yields hike up, the country will face a burden if having borrowed in international markets, and its ability to roll existing debt over at low cost is in fact squeezed. The fact that the country has to roll its debt over at high interest rates is detrimental to its fiscal prospect, making default more likely and the socio-economic condition more unstable.

Such a situation induces Credit Rating Agencies (CRAs) to downgrade the debt rating of the country or assign an increased probability of its default on debt obligations, implying higher borrowing costs in international markets (Boumparis, Milas, \& Panagiotidis, 2017). Since both corporate and sovereign debts are subject to the same country-specific macroeconomic risk factors, international creditors would handle their overall exposure to the country irrespective of whether lending is channelled to the public or to the private sector. Consequently, a rise in government debt pushes corporate borrowing costs higher for firms. For those reasons, firms facing market uncertainty for their output tend to postpone investment so as to fetch more relevant information to avoid the risk of failing, if not having to invest to preempt competitors (Dixit \& Pindyck, 1995; Guiso \& Parigi, 1999; Le, Hermes, \& Lanjouw, 2004; Mason \& Weeds, 2010; Nishide \& Yagi, 2016).

Nevertheless, although firms will invest less as the degree of output market uncertainty increases, the higher the internal funds (profits) firms have, the lower the negative impact of the uncertainty on investment (Minton \& Schrand, 1999; Ghosal \& Loungani, 2000; Peeters, 2001). Specifically, if profits go beyond a certain threshold, firms will raise investment. Such behaviour is due to two reasons. First, as profits are higher, it is easier for firms to diversify investments, thereby better managing risks. Second, higher profits make firm managers more ambitious in making breakthroughs and optimistic about future business prospects so that they tend to take risk regardless of output market uncertainty. This trend strengthens itself as successes have been previously achieved.

Given the above argument, the empirical model used to investigate the impact of profits on firm investment under output market uncertainty reads as follows:

$$
I N V_{i}=\beta_{0}+\beta_{1} U N C E R_{i}+\beta_{2} U N C E R_{i} \times P R O_{i}+\beta_{3} P R O_{i}+\varepsilon_{i}
$$


In Model (1), $I N V_{i}$ is the ratio of planned investment to current total fixed assets of firm $i . U N C E R_{i}$ is the degree of output market uncertainty, measured by the coefficient of variation (CV) of expected sales of firm $i$ (Guiso \& Parigi, 1999; Lensink, Van Steen \& Sterken, 2005). According to those studies, the higher the coefficient of variation of expected sales, the higher the output market uncertainty. Coefficient $\beta_{1}$ is expected to be negative since the theory postulates that output market uncertainty has negative impact on firm investment.

$P R O_{i}$ is the ratio of after-tax profits to total assets of firm $i$. Le et al. (2004), Le (2008), and Engel and Middendorf (2009) argue that firm investment is closely related to profits because it is difficult for firms to get access to external funds (for instance, bank credit) due to information asymmetry and limited liability, among others. Therefore, coefficient $\beta_{3}$ is supposed to be positive.

$U N C E R_{i} \times P R O_{i}$ is an interaction of $U N C E R_{i}$ and $P R O_{i}$, which is employed to examine the impact of profits on the relationship between output market uncertainty and investment of firm $i$. As just mentioned, several studies (for instance, Minton \& Schrand, 1999; Ghosal \& Loungani, 2000; Peeters, 2001) identify that the negative impact of output market uncertainty on high-profit firms is less severe than that on low-profit ones. Specifically, as profits go beyond a certain threshold, output market uncertainty triggers firm investment. This argument is clarified by Model (1). Taking the first derivative of $I N V_{i}$ with respect to $U N C E R_{i}$ gives:

$$
\frac{\partial I N V_{i}}{\partial U N C E R_{i}}=\beta_{1}+\beta_{2} P R O_{i}
$$

Expression (2) divulges that if profits are low $\left(P R O_{i} \rightarrow 0\right)$, output market uncertainty has negative impact on investment (since $\beta_{1}<0$ ) but that impact decreases in magnitude if profits go up. Specifically, as profits get over a certain benchmark (namely, $P R O_{i}>-\beta_{1} / \beta_{2}$ ), this relationship turns positive. If that is the case, $\beta_{2}$ should be positive.

To be complete, the empirical model should include other determinants of investment decisions identified by previous studies (for instance, Guiso \& Parigi, 1999; Engel \& Middendorf, 2009; Polder \& Veldhuizen, 2012) such as the irreversibility of used assets, growth rate of sales, degree of competition, bribes, and field of specialisation. Therefore, the empirical model is augmented to become:

$$
\begin{aligned}
& I N V_{i}=\beta_{0}+\beta_{1} U_{N C E R_{i}}+\beta_{2} U_{N C E R_{i}} \times P R O_{i}+\beta_{3} P R O_{i} \\
& +\beta_{4} I R R_{i}+\beta_{5} \text { RISK }_{i}+\beta_{6} D_{S A L_{i}}+\beta_{7} \text { COMP }_{i} \\
& +\beta_{8} C O M P_{i}^{2}+\beta_{9} B R I_{i}+\beta_{10} B R I_{i}^{2}+\beta_{11} M A N U_{i} \\
& +\beta_{12} S E R V_{i}+\varepsilon_{i}
\end{aligned}
$$


$I R R_{\mathrm{i}}$ is the irreversibility of used assets of firm $i$. To construct this variable, the manager was asked to evaluate the possibility to resell used assets to create variable $I R R 1_{i}$, which takes a value of 1 if the answer is "easy" and 0 if the answer is "not easy." We also use information about the expected resell value of used assets to create variable $I R R 2_{i}$ (i.e., the ratio of the expected resell value of used assets to their replacement costs). Since $I R R 1_{i}$ and $I R R 2_{i}$ are correlated, the factor analysis technique is used to combine them into one common factor (namely, $I R R_{\mathrm{i}}=w_{1} I R R 1_{i}+w_{2} I R R 2_{i}$, with $w_{1}$ and $w_{2}$ are factor scores) to proxy for the possibility to resell used assets of firm $i$. According to studies (Dixit \& Pindyck, 1995; Guiso \& Parigi, 1999), most investment decisions are irreversible because of constraints on reselling used assets. Therefore, if it is easier to resell and/or obtain higher values of resold assets, firms tend to invest more. Coefficient $\beta_{4}$ is thus supposed to be positive.

$\operatorname{RISK}_{i}$ is used to measure risk attitude of the top manager of firm $i$. To construct this variable, the manager was asked to choose between two cases: (1) investing a certain amount of money to earn $10 \%$ profit for sure, or (2) investing the same amount of money to earn $20 \%$ profit with a probability of $50 \%$ or nothing with the remaining probability of $50 \%$. The answers are used to measure risk attitude of firm manager $R I S K_{i}$, which takes a value of 0 (risk-averse) for the manager who chooses case (1) and 1 (risk-loving) for the one choosing case (2). Andrade and Stafford (2004) contend that risk-loving managers tend to invest more compared to risk-averse ones since they are more self-confident in own competence, especially in controlling market risk. Therefore, coefficient $\beta_{5}$ is supposed to be positive.

$D S A L_{i}$ is the annual growth rate of sales by firm $i(\%)$. Fast growth of sales means better prospects for firms, so they may make more investment to capture opportunities and expand market shares (Guiso \& Parigi, 1999; Guariglia, 2008; Engel \& Middendorf, 2009; Yang, Koveos, \& Barkley, 2015). As a result, coefficient $\beta_{6}$ is expected to be positive.

$C O M P_{i}$ is the degree of competition facing firm $i$, measured by its profit elasticity $\left(P E_{i}\right)$. PE were coined by such as Boone (2000) and further developed by Boone (2008), and Polder and Veldhuizen (2012). According to those studies, the degree of competition can be identified by the ratio of percentage change of profit $(\pi)$ to percentage change of marginal cost (MC), which means:

$$
P E_{i}=\frac{\Delta \pi_{i} / \pi_{i}(\%)}{\Delta M C_{i} / M C_{i}(\%)}
$$


Since it is often difficult to measure $\mathrm{MC}$, researchers replace it by average cost (AC). In addition, the average cost of firms that operate in different sectors will be the ratio of total cost (TC) to total revenue (TR), because it is not plausible to add up the quantity of different goods (Polder $\&$ Veldhuizen, 2012). In sum, $P E_{i}$ can be written as follows:

$$
P E_{i}=\frac{\Delta \bar{\pi}_{i} / \bar{\pi}_{i}(\%)}{\Delta A C_{i} / A C_{i}(\%)}<0, \bar{\pi}_{i}=\pi_{i} / T R_{i}
$$

As explained earlier, fierce competition may squeeze $P E_{i}$. Thus, in order to make it easier to grasp the impact of competition on investment, we use $C O M P_{i}=\left|P E_{i}\right|$. Higher value of $C O M P_{i}$ means higher degree of competition facing firm i. $C O M P_{i}^{2}$ is used to reveal the presence of an inverted U-shaped $(\cap)$ relationship between the degree of competition and investment by the firm. Nielsen (2002), Moretto (2008), Akdogu and MacKay (2008), and Polder and Veldhuizen (2012) assert that firms operating in a less severely competitive environment often have high costs due to moral hazard that results in inefficiency. As competition pressure strengthens, firms are forced to raise investment to mitigate costs, enhance efficiency, and preempt competitors so as to tackle the risk of squeezed market share. Yet, if competition pressure goes beyond a certain point, it becomes too fierce, market niche evaporates and the benefit from investing is no longer promising, firms will then scale down investment. Therefore, coefficient $\beta_{7}$ is expected to be positive and $\beta_{8}$ negative.

$B R I_{i}$ is the ratio of bribes that firm $i$ paid to government officials to its total assets. $B R I_{i}^{2}$ is included to detect the non-monotonic relationship between bribes and investment by the firm. If bribed, bureaucratic officials are greased to provide better services to firms, enabling them to take up available investment opportunities. However, despite being bribed, corrupt officials deliberately stay intact so as to urge firms to bribe more later on. If forced to bribe too much, expected profits from investment projects would go down and firms reduce investment accordingly. Thus, there exits an inverted U-shaped relationship between bribes and firm investment as well as growth (Svensson, 2005; Le, 2008). If so, $\beta_{9}$ is expected to be positive and $\beta_{10}$ to be negative.

$M A N U_{i}$ and $S E R V_{i}$ are included to test for the possible gap in investment among firms in different sectors (i.e., manufacturing, trade, and services). $M A N U_{i}$ takes a value of 1 for manufacturing firms and 0 otherwise. $S E R V_{i}$ takes a value of 1 for service firms and 0 otherwise. Coefficients $\beta_{11}$ and $\beta_{12}$ can be either positive or negative, depending on the environments in which firms operate. 


\section{RESEARCH METHODOLOGY}

Primary data used in this paper are directly collected from 667 non-state firms in the Mekong River Delta (Vietnam) in 2014. Based on a list of firms operating provided, we randomly select 200 non-state firms in Can Tho city and 100 firms in each of other provinces of the region to interview their top managers, using a questionnaire prepared in advance and corrected after several pilot surveys. Due to unexpected reasons (for instance, such as unable to contact the manager and missing information), we are able to get information from just 667 firms, consisting of 42 in An Giang province (accounting for $6.3 \%$ of the total number of the surveyed firms), 24 in Bac Lieu (3.6\%), 22 in Ben Tre (3.3\%), 44 in Ca Mau (6.6\%), 194 in Can Tho (29.1\%), 43 in Dong Thap (6.5\%), 53 in Hau Giang (7.9\%), 43 in Kien Giang (6.5\%), 52 in Long An (7.8\%), 44 in Soc Trang (6.6\%), 24 in Tien Giang (3.6\%), 25 in Tra Vinh (3.7\%), and 57 in Vinh Long (8.5\%).

The data collected include information about general characteristics, performance, actual investment in 2013, and planned investment in 2015 by the firms, among others. To give a full picture of the performance and investment of the surveyed firms, we use descriptive statistics. Then, Tobit model is utilised to estimate the impact of profits on the relationship between output market uncertainty and investment by the surveyed firms. ${ }^{1}$

\section{FINDINGS}

\section{Characteristics of the Surveyed Firms}

According to the survey, the average age of the firms is 10 years and their average assets in 2013 is VND146,913 million. A majority of them are liability-limited (accounting for as much as 34.6\% of the total number of the surveyed firms), joint-stock (28.9\%), and sole proprietorship firms $(27.0 \%)$. The number of firms that export products accounts for $23.1 \%$ of the total number of the firms, in which $87.7 \%$ of them operate in both domestic and foreign markets.

Average sales of the surveyed firms in 2013 is VND210,402 million (increasing by $17.4 \%$ compared to that in 2012). Their average profit is VND16,761 million (increasing by $6.8 \%$ compared to that in 2012) and returns on sales (ROS) is $8.0 \%$. However, the average cost went up markedly (by $18.4 \%$ compared to that in 2012). All this implies that the firms had reasonable growth rates but did not utilise resources well, so the cost is high. 
Le Khuong Ninh et al.

Table 1

General information about the surveyed firms (2013)

\begin{tabular}{lcccc}
\hline Indicators & Mean & Standard deviation & Min & Max \\
\hline Age (year) & 10 & 9 & 2 & 52 \\
Total assets (VND million) & 146,913 & 492,392 & 130 & $6,750,400$ \\
Sales (VND million) & 210,402 & 539,048 & 50 & $5,450,131$ \\
Profit (VND million) & 16,761 & 77,904 & $-705,087$ & $1,200,000$ \\
Investment (VND million) & 14,402 & 60,835 & 0 & 793,000 \\
\hline
\end{tabular}

Source: Authors' own survey in 2014

About $46.3 \%$ of the surveyed firms paid bribes and the average bribe per firm is as much as VND192.2 million per year. Bribing seems to be pervasive as $45.6 \%$ of the firms did it on purpose and $48.5 \%$ deem it as an implicit norm while doing business in Vietnam. Types of bribes that firms use are gifts (accounting for $56.0 \%$ of the total number of firms), travel $(54.3 \%)$, or in cash $(52.8 \%)$.

Table 2

Investment by the firms

\begin{tabular}{|c|c|c|c|c|c|}
\hline \multirow{2}{*}{ Financing sources } & \multicolumn{2}{|c|}{ Investment in 2013} & \multicolumn{2}{|c|}{$\begin{array}{l}\text { Planned investment in } \\
2015\end{array}$} & \multirow{2}{*}{$\begin{array}{c}\text { Change in } 2015 \\
\text { compared to } \\
2013(\%)\end{array}$} \\
\hline & $\begin{array}{c}\text { Amount } \\
\text { (VND million) }\end{array}$ & $\begin{array}{l}\% \text { of } \\
\text { total }\end{array}$ & $\begin{array}{c}\text { Amount } \\
\text { (VND million) }\end{array}$ & $\begin{array}{l}\% \text { of } \\
\text { total }\end{array}$ & \\
\hline Equity & $9,472.03$ & 65.77 & $5,142.61$ & 58.57 & -45.71 \\
\hline $\begin{array}{l}\text { Loans from joint-stock } \\
\text { banks }\end{array}$ & $2,976.26$ & 20.66 & $2,169.25$ & 24.71 & -27.11 \\
\hline Loans from state banks & $1,432.91$ & 9.95 & $1,022.82$ & 11.65 & -28.62 \\
\hline $\begin{array}{l}\text { Loans from foreign-owned } \\
\text { banks }\end{array}$ & 221.11 & 1.54 & 90.67 & 1.03 & -58.99 \\
\hline $\begin{array}{l}\text { Loans from government } \\
\text { projects }\end{array}$ & 30.58 & 0.21 & 19.34 & 0.22 & -36.76 \\
\hline Others & 269.51 & 1.87 & 335.13 & 3.82 & 24.35 \\
\hline Total investment & $14,402.41$ & 100.00 & $8,779.81$ & 100.00 & -39.04 \\
\hline
\end{tabular}

Source: Authors' own survey in 2014

Table 2 shows that the average investment by the firms in 2013 is VND14,402.4 million. Due to economic downturn and suppressed market demand, planned investment of the firms in 2015 is just VND8,779.8 million (decreasing by $39.04 \%$ compared to that in 2013). Financing sources for investment by the firms are equity (mainly retained profits) and bank loans that are much less than retained profits. According to the survey, retained profits are the most important financing source 
of investment by the firms. When making investment decisions, firm managers were also concerned with output market uncertainty. The coefficient of variation of the future sales of the firms is up to $37.7 \%$. Trading and production firms seem to feel more uncertain about markets (with the coefficient of variation of sales of 0.388 and 0.379 , respectively) compared to service firms $(0.360)$.

\section{Estimation Results}

Before running the regression, we carefully check the assumptions of the regression model regarding multicollinearity and heteroscedasticity. The results show that all the coefficients between independent variables $\left(r_{i j}\right)$ are smaller than $0.8\left(0.002 \leq\left|r_{i j}\right| 0.532\right)$. Moreover, since the relationship between $C O M P_{i}$ and $C O M P_{i}^{2}$ or between $B R I_{i}$ and $B R I_{i}^{2}$ is nonlinear, this regression does not violate the multicollinearity assumption of the classical model (Gujarati, 2004). We have also performed the White test for heteroscedasticity and found this problem $\left(p\right.$-value $\left.=9.436 \times 10^{-13}\right)$. Therefore, we use the Robust estimation option of Stata to correct it.

The result in column 2 of Table 3 (Model 2a) shows that if not taking account of $P R O_{i}$ and $U N C E R_{i} \times P R O_{i}$, coefficient $\beta_{1}$ of $U N C E R_{i}$ is negative $(-0.124)$ at a significance level of $10 \%$, implying that output market uncertainty alone has a negative impact on investment by the surveyed firms. Variable $P R O_{i}$ is added in Model $2 \mathrm{~b}$ (column 3 of Table 3 ) to empirically examine the dependence of investment on profits. Coefficient $\beta_{3}$ of this variable is 0.248 at a significance level of $1 \%$, revealing that the higher the profits, the more firms tend to invest.

Model $2 \mathrm{c}$ is used to estimate the impact of profits on the relationship between output market uncertainty and firm investment (column 4 of Table 3 ). The result reveals that coefficient $\beta_{2}$ of the interactive term $U N C E R_{i} \times P R O_{i}$ has a positive value of 0.610 at a significance level of $1 \%$ and coefficient $\beta_{1}$ of $U N C E R_{i}$ has a negative value of -0.226 at a significance level of $1 \%$. This is supportive evidence for the point of view that higher profits mitigate the negative impact of output market uncertainty on firm investment. Moreover, if profits go over a certain level $(0.369),{ }^{2}$ firms tend to raise investment as output market uncertainty picks up.

Our finding is quite identical to those of several studies (for instance, Minton \& Schrand, 1999; Ghosal \& Loungani, 2000; Peeters, 2001), which divulged that the negative impact of output market uncertainty on high-profit firms is less severe than that on low-profit ones. Moreover, we found that as profits go beyond a certain threshold (0.369), output market uncertainty triggers firm investment, thereby adding interesting evidence to the investment literature. 
Le Khuong Ninh et al.

Table 3

Estimation results

Dependent variable: INV

\begin{tabular}{|c|c|c|c|}
\hline & Model 2a & Model 2b & Model 2c \\
\hline$(1)$ & (2) & (3) & $(4)$ \\
\hline Constant C & -0.031 & $-0.075^{*}$ & -0.032 \\
\hline$U N C E R_{i}$ & $\begin{array}{l}-0.124^{*} \\
(-0.047)\end{array}$ & $\begin{array}{l}-0.127^{*} \\
(-0.049)\end{array}$ & $\begin{array}{c}-0.226^{* * *} \\
(-0.087)\end{array}$ \\
\hline$U_{N C E R_{i}} \times P R O_{i}$ & & & $\begin{array}{l}0.610^{* * * *} \\
(0.236)\end{array}$ \\
\hline PROi & & $\begin{array}{l}0.248^{* * *} \\
(0.096)\end{array}$ & \\
\hline$I R R_{i}$ & $\begin{array}{c}0.048^{* * *} \\
(0.018)\end{array}$ & $\begin{array}{c}0.048^{* * *} \\
(0.019)\end{array}$ & $\begin{array}{c}0.045^{* * *} \\
(0.018)\end{array}$ \\
\hline RISK $_{i}$ & $\begin{array}{l}0.102^{* *} \\
(0.043)\end{array}$ & $\begin{array}{l}0.089^{* *} \\
(0.037)\end{array}$ & $\begin{array}{l}0.101^{* *} \\
(0.042)\end{array}$ \\
\hline$D S A L_{i}$ & $\begin{array}{l}0.002^{* * *} \\
(0.001)\end{array}$ & $\begin{array}{l}0.002^{* * *} \\
(0.001)\end{array}$ & $\begin{array}{l}0.002^{* * *} \\
(0.001)\end{array}$ \\
\hline $\operatorname{COMP}_{i}$ & $\begin{array}{l}0.004^{* *} \\
(0.002)\end{array}$ & $\begin{array}{l}0.005^{* * *} \\
(0.002)\end{array}$ & $\begin{array}{l}0.005^{* * *} \\
(0.002)\end{array}$ \\
\hline $\operatorname{COMP}_{i}^{2}$ & $\begin{array}{l}0.000^{*} \\
(0.000)\end{array}$ & $\begin{array}{l}0.000^{* *} \\
(0.000)\end{array}$ & $\begin{array}{l}0.000^{* *} \\
(0.000)\end{array}$ \\
\hline$B R I_{i}$ & $\begin{array}{l}8.849^{* * *} \\
(3.385)\end{array}$ & $\begin{array}{l}7.708^{* * *} \\
(2.970)\end{array}$ & $\begin{array}{l}7.339^{* * *} \\
(2.833)\end{array}$ \\
\hline$B R I_{i}^{2}$ & $\begin{array}{l}-64.419^{* *} \\
(-24.640)\end{array}$ & $\begin{array}{l}-61.337^{* *} \\
(-23.634)\end{array}$ & $\begin{array}{l}-55.166^{*} \\
(-21.296)\end{array}$ \\
\hline$M A N U_{i}$ & $\begin{array}{c}-0.025 \\
(-0.009)\end{array}$ & $\begin{array}{c}-0.022 \\
(-0.008)\end{array}$ & $\begin{array}{c}-0.024 \\
(-0.009)\end{array}$ \\
\hline$S E R V_{i}$ & $\begin{array}{c}-0.052 \\
(-0.019)\end{array}$ & $\begin{array}{c}-0.051 \\
(-0.019)\end{array}$ & $\begin{array}{c}-0.058 \\
(-0.021)\end{array}$ \\
\hline Observations & 667 & 667 & 667 \\
\hline$\chi^{2}$ & 51.240 & 77.370 & 78.710 \\
\hline Significance & 0.000 & 0.000 & 0.000 \\
\hline Log likelihood & -346.585 & -333.517 & -332.847 \\
\hline
\end{tabular}

Source: Authors' own survey in 2014

Notes: Numbers in the first line of each rows are coefficient $\beta_{i}$. Numbers in the parentheses are $\partial I N V / \partial X_{i}$. $* * * 1 \%$ significance level; ** 5\% significance level; * 10\% significance level 
Coefficient of $I R R_{i}$ also has a positive value at a significance level of $1 \%$, implying that the easier it is to resell used assets, the higher the level of investment is. ${ }^{3}$ Likewise, coefficients of $R I S K_{i}$ and $D S A L_{i}$ also have a positive value at the significance level of $5 \%$ and $1 \%$, respectively. Coefficients of other variables (namely, $C O M P_{i}, C O M P_{i}^{2}, B R I_{i}$ and $B R I_{i}^{2}$ ) have expected signs, except for $M A N U_{i}$ and $S E R V_{i}$.

Interestingly, we found the inverted U-shaped relationship between bribes and firm investment, meaning that bribes trigger investment but after a certain threshold that positive effect will deteriorate. As a matter of fact, institution plays a key role since it provides firms with guidance and certain routines, thereby reducing economic and market uncertainties (Uzzi, 1997; Graeff, 2005; North, 2005; Bruton, Ahlstrom \& Obloj, 2008). However, firms in transition countries face many difficulties due to deficiencies of the legal system and financial markets (Scase, 1997). Therefore, networking turns out to be a common practice and political connections become extremely important for firms in those countries (Yiu \& Lau, 2008). This relationship is meant to trigger bribery behaviour of firms in order to create and maintain networks, thereby enhancing the ability to grasp investment opportunities.

Although bribes brought about advantages for firms, after going beyond a certain point bribes may crowd out investments and corrode incentives for innovation (Luo, 2004). In addition, bribes do not necessarily guarantee good performances because firms that have paid bribes may face more severe demands by corrupt officials. As a result, the more bribes firms pay, the more inefficient resources allocation and lower investment would be (De Jong et al., 2012).

\section{CONCLUSION AND RECOMMENDATIONS}

Output market uncertainty is a key element that affects firm investment. Nevertheless, the relationship between investment and output market uncertainty depends on profits. Hence, this paper concentrates on empirically examining the impact of profits on the relationship between investment and output market uncertainty of 667 non-state firms in Vietnam using Tobit model. The findings show that most independent variables of the empirical model have coefficients that are statistically significant as predicted by the theory (for instance, output market uncertainty alone has a negative impact on investment of the firms). It is worth noting that higher profits are associated with reduced negative impact of output market uncertainty on investment of the firms. Especially, if profits go over 
a certain level, an increase in the degree of output market uncertainty induce firms to invest more, so over-investment is very likely to occur.

In addition, the relationship of the degree of competition on investment of the firms has an inverted U-shaped, implying that low degree of competition stimulates investment but if competition pressure becomes too fierce, firms will scale down investment to avoid unexpected loss. The relationship between bribes on firm investment is also in the form of inverted U-shaped while higher growth rates of sales and higher reversibility of used assets do encourage firms to invest more. However, bribes seem to be costly for the firms, so those that have to pay too much bribes tend to invest less.

The findings give some thoughts that should be taken into account to enhance efficiency and ensure sustainable growth of firms. Firms need to set up a specialised department in charge of forecasting market tendency so as to have proper investment strategies that help avoid over-investment adversely induced by high profits. The government may pay more attention to moderate competition. When monopoly exists, it is desirable to remove barriers to firm entry to stimulate them to enter markets. When the level of competition is too fierce, the government may tight up regulations in terms of eliminating inefficient firms to ensure that markets operate effectively.

Moreover, in order to contain bribery phenomenon that seems to be pervasive, there is an urgent need to make administrative procedures transparent. More importantly, the government may reform the salary policy and re-allocate discretionary power to avoid power concentration that makes it difficult to manipulate or extort bribes. In addition, second-hand goods market should be established and endorsed in order to better price used assets of firms, thereby promoting their investment.

\section{NOTES}

1. We have also applied Ridge regression to the empirical model and come up with almost the same result.

2. Taking the first derivative of $I N V_{i}$ with respect to $U N C E R_{i}: \partial I N V / \partial U N C E R=$ $-0.087+0,236 \times P R O$. Let $\partial I N V / \partial U N C E R=0 \Rightarrow P R O=0.369$.

3. Factor analysis results show that IRR $-0.609 I R R 1_{i}+0.609 I R R 2_{i}$ 


\section{REFERENCES}

Aggarwal, R.K., \& Samwick, A.A. (2006). Empire-builders and shirkers: Investment, firm performance, and managerial incentives. Journal of Corporate Finance, 12(3), 489-515. https://doi.org/10.1016/j.jcorpfin.2006.01.001

Akdogu, E., \& MacKay, P. (2008). Investment and competition. Journal of Financial and Quantitative Analysis, 43(2), 299-330. https://doi.org/10.1017/ S0022109000003537

Andrade, G., \& Stafford, E. (2004). Investigating the economic role of mergers. Journal of Corporate Finance, 10(1), 1-36. https://doi.org/10.1016/S0929-1199(02)000238

Boone, J. (2000). Competitive pressure: The effects on investments in product and process innovation. Rand Journal of Economics, 31(3), 549-569.

Boone, J. (2008). A new way to measure competition. Economic Journal, 118(531), 12451261. https://doi.org/10.1111/j.1468-0297.2008.02168.x

Boumparis, P., Milas, C., \& Panagiotidis, T. (2017). Economic policy uncertainty and sovereign credit rating decisions: Panel quantile evidence for the Eurozone. Journal of International Money and Finance, 79(December), 39-71. https://doi. org/10.1016/j.jimonfin.2017.08.007

Bruton, G.D., Ahlstrom, D., \& Obloj, K. (2008). Entrepreneurship in emerging economies: Where are we today and where should the research go in the future. Entrepreneurship Theory and Practice, 32(1), 1-14. https://doi.org/10.1111/ j.1540-6520.2007.00213.x

De Jong, G., Tu, P.A., \& van Ees, H. (2012). Which entrepreneurs bribe and what do they get from it? Exploratory evidence from Vietnam. Entrepreneurship Theory and Practice, 36(2), 323-345. https://doi.org/10.1111/j.1540-6520.2010.00400.x

Deltas, G. (2006). Overinvestment in partially relationship-specific assets and R\&D. Quarterly Review of Economics and Finance, 46(3), 466-475. https://doi. org/10.1016/j.qref.2005.06.001

Dergiades, T., Milas, C., \& Panagiotidis, T. (2015). Tweets, Google trends, and sovereign spreads in the GIIPS. Oxford Economic Papers, 67(2), 406-432. https://doi. org/10.1093/oep/gpu046

Dixit, A.K., \& Pindyck, R.S. (1995). The option approach to capital investment. Harvard Business Review, May \& June, 105-115.

Engel, D., \& Middendorf, T. (2009). Investment, internal funds and public banking in Germany. Journal of Banking and Finance, 33(11), 2132-2139. https://doi. org/10.1016/j.jbankfin.2009.05.006

Fu, F. (2010). Overinvestment and the operating performance of SEO firms. Financial Management, 39(1), 249-272. https://doi.org/10.1111/j.1755-053X.2010.01072.x

Ghosal, V., \& Loungani, P. (2000). The differential impact of uncertainty on investment in small and large businesses. Review of Economics and Statistics, 82(2), 338-343. https://doi.org/10.1162/003465300558722

Graeff, P. (2005). Why should one trust in corruption? The linkage between corruption, norms, and social capital. In J.G. Lambsdorf, M. Taube, \& M. Schramm (Eds.), The new institutionalism of corruption (pp. 40-58). London: Routledge. 
Guariglia, A. (2008). Internal financial constraints, external financial constraints, and investment choice: Evidence from a panel of UK firms. Journal of Banking and Finance, 32(9), 1795-1809. https://doi.org/10.1016/j.jbankfin.2007.12.008

Gujarati, N.D. (2004). Basic econometrics (4th ed.). USA: McGraw-Hill.

Guiso, L., \& Parigi, G. (1999). Investment and demand uncertainty. Quarterly Journal of Economics, 114(1), 185-227. https://doi.org/10.1162/003355399555981

Jorgenson, D.W. (1963). Capital theory and investment behavior. American Economic Review Papers and Proceedings, 53(2), 247-259.

Le, K.N. (2008). Impact of bribes on investment by non-state firms in the Mekong River Delta (MRD). Economic Studies, 3, 68-76.

Le, K.N., Hermes, N., \& Lanjouw, G. (2004). Investment, uncertainty and irreversibility: An empirical study of rice mills in the Mekong River Delta, Vietnam. Economics of Transition, 12(2), 307-332. https://doi.org/10.1111/j.0967-0750.2004.00180.x

Lensink, R., Van Steen, P., \& Sterken, E. (2005). Uncertainty and growth of the firm. Small Business Economics, 24(4), 381-391. https://doi.org/10.1007/s11187-005-7121-z

Lin, Y., Hu, S., \& Chen, M. (2005). Managerial optimism and corporate investment: Some empirical evidence from Taiwan. Pacific-Basin Finance Journal, 13(5), 523-546. https://doi.org/10.1016/j.pacfin.2004.12.003

Liu, Y., \& Jiang, I. (2012). Influence of investor subjective judgments in investment decision-making. International Review of Economics and Finance, 24, 129-142. https://doi.org/10.1016/j.iref.2012.01.002

Luo, Y. (2004). An organizational perspective of corruption. Management and Organization Review, 1(1), 119-154. https://doi.org/10.1111/j.1740-8784.2004.00006.x

Mason, R., \& Weeds, H. (2010). Investment, uncertainty and preemption. International Journal of Industrial Organization, 28(3), 278-287. https://doi.org/10.1016/j. ijindorg.2009.09.004

Minton, B.A., \& Schrand, C. (1999). The impact of cash flow volatility on discretionary investment and the costs of debt and equity financing. Journal of Financial Economics, 54(3), 423-460. https://doi.org/10.1016/S0304-405X(99)00042-2

Moretto, M. (2008). Competition and irreversible investments under uncertainty. Information Economics and Policy, 20(1), 75-88. https://doi.org/10.1016/j. infoecopol.2007.10.002

Nielsen, M.J. (2002). Competition and irreversible investments. International Journal of Industrial Organization, 20(5), 731-743. https://doi.org/10.1016/S01677187(01)00057-1

Nishide, K., \& Yagi, K. (2016). Investment under regime uncertainty: Impact of competition and preemption. International Journal of Industrial Organization, 45(March), 47-58. https://doi.org/10.1016/j.ijindorg.2016.01.001

North, D. (2005). Understanding the process of economic change. Princeton, NJ: Princeton University Press. https://doi.org/10.1515/9781400829484

Peeters, M. (2001). Does demand and price uncertainty affect Belgian and Spanish corporate investment? Louvain Economic Review, 67(3), 235-255.

Peng, M.W., \& Heath, P.S. (1996). The growth of the firm in planned economies in transition: Institutions, organizations, and strategic choice. Academy of Management Review, 21(2), 492-528. https://doi.org/10.5465/amr.1996.9605060220 
Pinheiro, M. (2008). Overinvestment and fraud. Journal of Mathematical Economics, 44(5-6), 484-512. https://doi.org/10.1016/j.jmateco.2007.10.004

Polder, M., \& Veldhuizen, E. (2012). Innovation and competition in the Netherlands: Testing the inverted-U for industries and firms. Journal of Industry, Competition and Trade, 12(1), 67-91. https://doi.org/10.1007/s10842-011-0120-7

Scase, R. (1997). The role of small businesses in the economic transformation of Eastern Europe: Real but relatively unimportant. International Small Business Journal, 16(1), 113-121. https://doi.org/10.1177/0266242697161001

Stiglitz, J.E., \& Weiss, A. (1981). Credit rationing in markets with imperfect information. American Economic Review, 71(3), 393-410.

Svensson, J. (2005). Eight questions about corruption. Journal of Economic Perspectives, 19(3), 19-42. https://doi.org/10.1257/089533005774357860

Uzzi, B. (1997). Social structure and competition in interfirm networks: The paradox of embeddedness. Administrative Science Quarterly, 42(1), 35-67. https://doi. org/10.2307/2393808

Yang, I., Koveos, P., \& Barkley, T. (2015). Permanent sales increase and investment. Journal of Empirical Finance, 34(December), 15-33. https://doi.org/10.1016/j. jempfin.2015.08.004

Yiu, D.W., \& Lau, D.M. (2008). Corporate entrepreneurship as resource capital in emerging markets. Entrepreneurship Theory and Practice, 32(1), 37-57. https://doi.org/10.1111/j.1540-6520.2007.00215.x 